INTERNATIONAL JOURNAL OF ENVIRONMENT

Volume-6, Issue-3, Jun-Aug 2017

Received:29 June
Revised:5 August

\title{
SOIL FERTILITY ASSESSMENT AND MAPPING OF AGRICULTURAL RESEARCH STATION, JAUBARI, ILLAM, NEPAL
}

Dinesh Khadka ${ }^{1}$, Sushil Lamichhane ${ }^{1}$, Keshav Shrestha ${ }^{2}$, Sushila Joshi ${ }^{1}$, Manoj Karna ${ }^{2}$, Buddhi B. Pant $^{1}$ and Surendra Yadav $^{2}$

${ }^{1}$ Soil Science Division, NARC, Khumaltar, Lalitpur, Nepal

${ }^{2}$ Agricultural Research Station, NARC, Jaubari, Illam, Nepal

*Corresponding author: dinesh.khadka92@gmail.com

\begin{abstract}
Soil fertility evaluation is a prerequisite factor for sustainable planning of a particular region. Considering this, a study was conducted to determine the soil fertility status of the Agricultural Research Station, Jaubari, Illam, Nepal. In total, 78 soil samples were collected using soil sampling auger randomly from a depth of 0-20 cm. The texture, $\mathrm{pH}, \mathrm{OM}, \mathrm{N}, \mathrm{P}_{2} \mathrm{O}_{5}, \mathrm{~K}_{2} \mathrm{O}, \mathrm{Ca}, \mathrm{Mg}, \mathrm{S}, \mathrm{B}, \mathrm{Fe}, \mathrm{Zn}, \mathrm{Cu}$ and $\mathrm{Mn}$ status of the samples were analyzed in the laboratory of Soil Science Division, Khumaltar by following standard analytical methods. The soil fertility maps of the observed parameters were prepared through Arc-GIS 10.1 software. The observed data revealed that soil was brown (10YR 4/3), dark grayish brown (10YR 4/2), dark yellowish brown (10YR 4/4) and yellowish brown (10YR 5/6) in colour, and the structure was granular. Similarly, the sand, silt and clay content were $53.84 \pm 1.06 \%, 34.34 \pm 0.83 \%$ and $11.82 \pm 0.47 \%$, respectively and were indicated as sandy loam and loam in texture. The soil was very acidic ( $\mathrm{pH}$ $3.85 \pm 0.04)$, and very low in available boron $(0.26 \pm 0.06 \mathrm{mg} / \mathrm{kg})$ and available sulphur $(0.59 \pm 0.15 \mathrm{mg} / \mathrm{kg})$. The available calcium $(188.7 \pm 31.30 \mathrm{mg} / \mathrm{kg})$, available magnesium $(50.98 \pm 5.0 \mathrm{mg} / \mathrm{kg})$ and available manganese $(5.16 \pm 0.90 \mathrm{mg} / \mathrm{kg})$ were low. Likewise, available potassium $(110.91 \pm 7.30 \mathrm{mg} / \mathrm{kg})$, available zinc $(1.19 \pm 0.31 \mathrm{mg} / \mathrm{kg})$ and available copper $(0.95 \pm 0.05 \mathrm{mg} / \mathrm{kg})$ content were medium. Similarly, organic matter $(7.88 \pm 0.32 \%)$, total nitrogen $(0.27 \pm 0.01 \%)$ and available phosphorus $(36.53 \pm 5.66 \mathrm{mg} / \mathrm{kg})$ were high, and available iron $(39.5 \pm 2.17 \mathrm{mg} / \mathrm{kg})$ was very high.

Keywords: Soil fertility maps; Soil properties; Soil testing; Arc-GIS; ARS Jaubari
\end{abstract}




\section{Introduction}

Soil is most vital resource for improving the quality of human life and plays an important role in agricultural development (Das et al., 2009). Fertile and productive soils are vital components of stable societies because they ensure growth of plants needed for food, fibre, animal feed and forage, medicines, industrial products, energy and for an aesthetically pleasing environment. Soil fertility focuses on optimum supply of nutrients to satisfy the needs of plants. Soil fertility of an area declines periodically due to various natural and human influenced factors. The inadequate soil fertility is a major constraint for sustained agricultural development in different sites of Nepal (Khadka et al., 2016a; Khadka et al., 2016b; Khadka et al., 2016c; Khadka et al., 2016d; Khadka et al., 2017).

The evaluation of soil fertility is perhaps the most basic decision making tool in order to plan efficient land use system (Havlin et al., 2010).Evaluation of soil fertility is now becoming a routine work for soil management and crop production. Among the different methods of soil fertility evaluation, soil testing is most popular in the world (Panda, 2010).Soil testing provides information regarding nutrient availability in soils which forms the basis for the fertilizer recommendations for maximizing crop yields. The texture, structure, colour etc. are important soil physical parameters. Similarly, soil reaction $(\mathrm{pH})$, organic matter, macro and micronutrients etc. are also important soil chemical parameters. These parameters are determined effectively after analyzing soil samples in the laboratory.

The soil properties may vary spatially from a field to a larger regional scale probably due to the variation in soil forming factors, which can be termed as intensive and extrinsic factors such as soil management practices, fertility status, crop rotation, slopes, precipitation etc. (Cambardella and Karlen, 1999). The two new technologies namely Global Positioning Systems (GPS) and Geographic Information Systems (GIS) introduced latter play important role for describing the spatial variability of soil fertility across a field. Such modern geospatial technologies as Geographical Information System (GIS) and Global Positioning System (GPS) offer enormous potential for soil and water resources development and management (Rao et al., 1997; Das, 2004).GIS is a most potential tool used for easy access, retrieval and manipulation of voluminous data of natural resources efficiently which is difficult to handle manually. Similarly, it 
facilitates manipulation of spatial and attributes data useful for handling multiple data of diverse origin (Mandal and Sharma, 2010). Moreover, Collection of soil samples by using GPS is very important for preparing thematic soil fertility maps (Mishra et al., 2013). This instrument helps to identify latitude, longitude and elevation of the soil sampling points.

Nepal Agricultural Research Council (NARC) was established to strengthen agriculture sector in the country through agriculture research. Agricultural Research Station, Jaubari, Illam is an important wing among the research farms of NARC, in order to generate appropriate agriculture production technologies for eastern high hills of Nepal. This research farm has been recently established and the research works are in initial phase. Studies related to the soil fertility status of Agricultural Research Station, Jaubari, Illam have not been done yet. Therefore, it is important to investigate the soil fertility status and may provide valuable information relating to agriculture research. Considering this, a study was done with the objective to assess and map the soil fertility status of Agricultural Research Station, Jaubari, Illam, Nepal.

\section{Materials and Methods}

\section{Study Area}

The study was carried out at recently established research site Agricultural Research Station, Jaubari, Illam, Nepal (Figure 1). The research farm is situated at the latitude $27.032278^{\circ} \mathrm{N}$ and longitude $88.042917^{\circ} \mathrm{E}$ as well altitude $2870 \mathrm{masl}$. The upper site of the farm is denoted A block, whereas lower site of the farm is denoted B block. The office area is situated in the block A. Similarly, Block A is more sloping than Block B. The other site (larger area) shown in the map is forest land, and not used for cultivation yet. The potato, wheat, apple, radish etc. are the crops that possess during soil sampling in the field. Similarly, fallow land was also shown in some sites of the farm. Being eastern high hill site, precipitation is high and temperature is cool all throughout the year.

\section{Soil Sampling}

The surface sampling (0-20 cm depth) was done from different sites of Agricultural Research Station, Jaubari, Illam, Nepal during April 2016. The soil sampling was done only from the block used for cultivation i.e. A and B. Altogether 78 soil samples were collected from the research farm by using a soil 
sampling auger (Figure 2). The exact locations of the samples were recorded using a handheld GPS receiver. The random method based on the variability of the land was used for collecting soil samples.

Laboratory Analysis

All the soil samples were analyzed at the laboratory of Soil Science Division, Khumaltar. The different soil parameters tested as well as methods adopted to analyze are shown in the Table 1.

Statistical Analysis

Descriptive statistics (mean, range, standard deviation, standard error, coefficient of variation) of soil parameters were computed initially using the Minitab 17 package. Interpretations (very low, low, medium, high and very high) of determined values were done based on Soil Science Division, Khumaltar. Similarly, the coefficient of variation (CV) was also ranked for determination of nutrient variability in the field according to the procedure of (Aweto, 1982) where, CV $<25 \%$ denotes low variation, $\mathrm{CV}>25 \leq 50 \%$ denotes moderate variation, $\mathrm{CV}>50 \%$ denotes high variation. Moreover, Arc Map 10.1 with geostatistical analyst extension of Arc GIS software was used to prepare soil fertility maps, while interpolation method employed was ordinary kriging with stable semi-variogram. Likewise, the nutrient index was also determined by the formula given by Ramamoorthy and Bajaj (1969).

Nutrient index (N.I.) $=\left(\mathrm{N}_{\mathrm{L}} \times 1+\mathrm{N}_{\mathrm{M}} \times 2+\mathrm{N}_{\mathrm{H}} \times 3\right) / \mathrm{N}_{\mathrm{T}}$

Where, $\mathrm{N}_{\mathrm{L}}, \mathrm{N}_{\mathrm{M}}$ and $\mathrm{N}_{\mathrm{H}}$ means number of samples ranked in low, medium and high classes of nutrient status, respectively and $\mathrm{N}_{\mathrm{T}}$ means total number of samples used for the study. Similarly, interpretation was done as value given by Ramamoorthy shown on the Table 2 . 
Table 1. Parameters and Methods Adopted for the Laboratory Analysis at Soil Science Division,

Khumaltar

\begin{tabular}{llll}
\hline S.N. & Parameters & Unit & Methods \\
\hline 1. & Physical & & \\
& Soil texture & Hydrometer (Bouyoucos, 1927) \\
& Soil colour & & Munshell-colour chart \\
& Soil structure & & Field-feel \\
2. & Chemical & & \\
& Soil $\mathrm{pH}$ & & Potentiometric 1:2 (Jackson, 1973) \\
Organic matter & $\%$ & Walkely and Black (Walkely and Black, 1934) \\
Total $\mathrm{N}$ & $\%$ & Kjeldahl (Bremner and Mulvaney, 1982) \\
Available $\mathrm{P}_{2} \mathrm{O}_{5}$ & $\mathrm{mg} / \mathrm{kg}$ & Olsen's (Olsen et al., 1954) \\
Available $\mathrm{K}_{2} \mathrm{O}$ & $\mathrm{mg} / \mathrm{kg}$ & Ammonium acetate (Jackson, 1967) \\
Available $\mathrm{Ca}$ & $\mathrm{mg} / \mathrm{kg}$ & EDTA Titration (El Mahi et al.,1987) \\
Available $\mathrm{Mg}$ & $\mathrm{mg} / \mathrm{kg}$ & EDTA Titration (El Mahi et al.,1987) \\
Available $\mathrm{S}$ & $\mathrm{mg} / \mathrm{kg}$ & Turbidimetric (Verma, 1977) \\
Available B & $\mathrm{mg} / \mathrm{kg}$ & Hot water (Berger and Truog, 1939) \\
Available Fe & $\mathrm{mg} / \mathrm{kg}$ & DTPA (Lindsay and Norvell, 1978) \\
Available Zn & $\mathrm{mg} / \mathrm{kg}$ & DTPA (Lindsay and Norvell, 1978) \\
Available Cu & $\mathrm{mg} / \mathrm{kg}$ & DTPA (Lindsay and Norvell, 1978) \\
Available $\mathrm{Mn}$ & $\mathrm{mg} / \mathrm{kg}$ & DTPA (Lindsay and Norvell, 1978) \\
\hline
\end{tabular}

Table 2. Rating Chart of Nutrient index

\begin{tabular}{ccc}
\hline S.N. & Nutrient Index & Value \\
\hline 1. & Low & $<1.67$ \\
2. & Medium & $1.67-2.33$ \\
3. & High & $>2.33$ \\
\hline
\end{tabular}




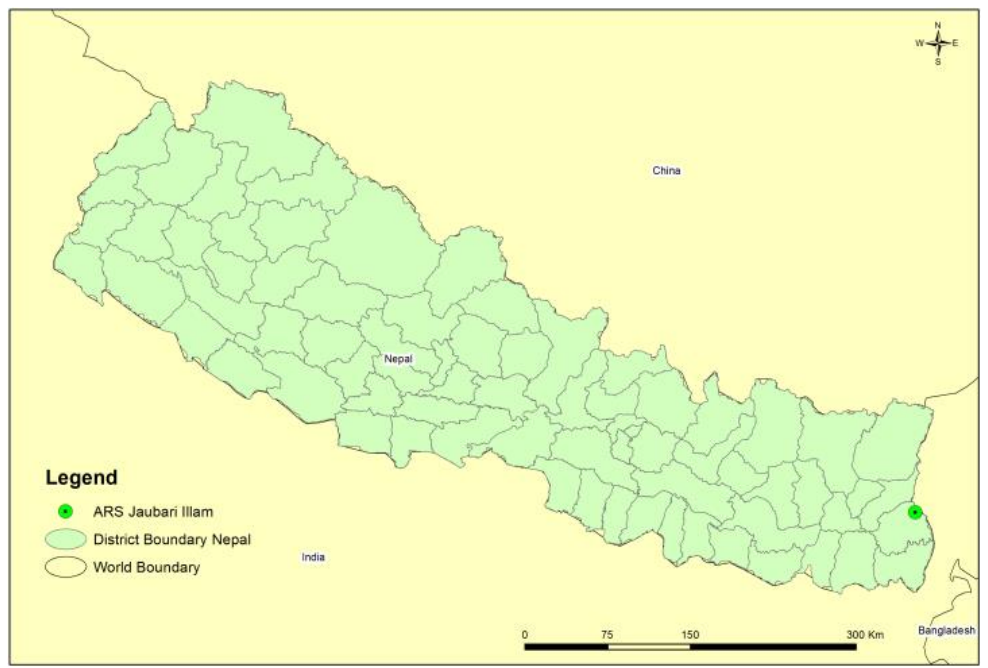

Figure 1.Location Map of Agricultural Research Station, Jaubari, Illam, Nepal

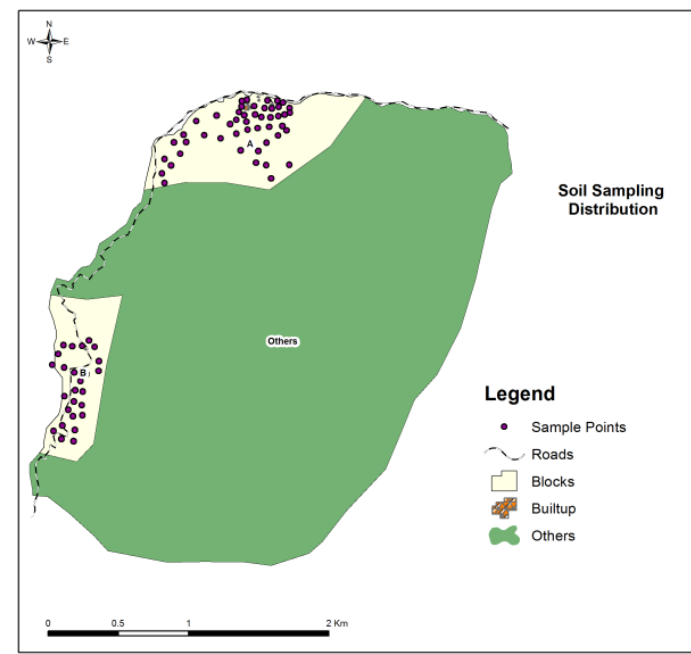

Figure 2.Distribution of Soil Sample Points During Soil Sampling

\section{Results and Discussion}

The soil fertility status of the studied site was assessed with respect to texture, colour, structure, $\mathrm{pH}$, organic matter, primary nutrients, secondary nutrients and micronutrients such as $\mathrm{B}, \mathrm{Fe}, \mathrm{Zn}, \mathrm{Cu}$, and $\mathrm{Mn}$, and the results obtained are presented and discussed in the following headings.

Soil Texture

Texture has been considered as an indicator in several studies (Grace and Weier, 2007; Pattison et al., 2008) and is an important physical property for characterizing soils. The infiltration and retention of water, 
soil aeration, absorption of nutrients, microbial activities, tillage and irrigation practices etc. becomes affected due to texture (Gupta, 2004). The sand, silt and clay are the three components of texture. The sand of soil samples ranged from 34 to $79.4 \%$ with a mean of $53.84 \%$ and that of silt were 14.5 to $52.8 \%$ with a mean of $34.34 \%$, while the range of clay were 6.1 to $23.2 \%$ with a mean of $11.82 \%$ (Table 3 ). This shows loam and sandy loam texture (Figure 3). The coefficients of variation between the soil samples were low for sand (16.92\%) and silt (20.7\%), while moderate for clay $(34.06 \%)$. The determined texture is satisfactory for agriculture purpose.

Table 3. Soil Texture Status of Agricultural Research Station, Jaubari, Illam, Nepal

\begin{tabular}{llll}
\hline \multirow{2}{*}{ Descriptive Statistics } & \multicolumn{3}{c}{ Soil separates } \\
\cline { 2 - 4 } & Sand & Silt & Clay \\
\cline { 2 - 4 } & 53.84 & 34.34 & 11.82 \\
Mean & 1.06 & 0.83 & 0.47 \\
SEM & 9.11 & 7.11 & 4.03 \\
Minimum & 34.00 & 14.50 & 6.10 \\
Maximum & 79.40 & 52.80 & 23.20 \\
CV\% & 16.92 & 20.70 & 34.06 \\
Class & Loam; Sandy Loam & \\
\hline
\end{tabular}

$S E M=$ Standard error of the mean SD=Standard deviation

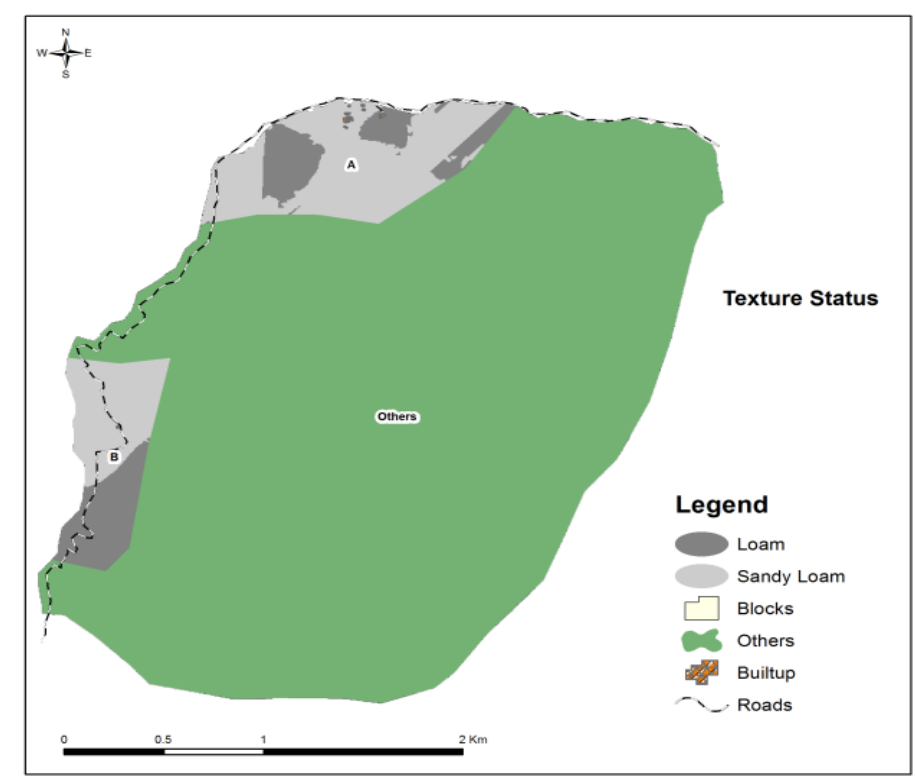

Figure 3. Soil Texture Status of Agricultural Research Station, Jaubari, Illam, Nepal 


\section{Soil Colour}

Soil colour is an indirect measure of other important characteristics such as water drainage, aeration, and organic matter content of soils (Foth, 1990). Three kinds of soil colour; brown (10YR 4/3), dark grayish brown (10YR 4/2) and dark yellowish brown (10YR 4/4) were observed in block A. Moreover, yellowish brown (10YR 5/6) and dark yellowish brown (10YR 4/4) colour were observed in block B.

\section{Soil Structure}

Soil structure refers to the pattern of spatial arrangement of soil particles in a soil mass (Brady and Weil, 2004). It is a vital physical property of soil. The granular kind of structure was observed in all the sites. This farm was away from human threatening activity or undisturbed from longer period might be the cause of very good structure i.e. granular.

Table 4. Soil Fertility Status of Agricultural Research Station, Jaubari, Illam, Nepal

\begin{tabular}{|c|c|c|c|c|c|}
\hline \multirow{3}{*}{ Descriptive Statistics } & \multicolumn{5}{|c|}{ Soil Fertility Parameters } \\
\hline & \multirow[t]{2}{*}{$\mathrm{pH}$} & $\mathrm{OM}$ & $\mathrm{N}$ & $\mathrm{P}_{2} \mathrm{O}_{5}$ & $\mathrm{~K}_{2} \mathrm{O}$ \\
\hline & & \multicolumn{2}{|c|}{$\%$} & \multicolumn{2}{|c|}{$\mathrm{mg} / \mathrm{kg}$} \\
\hline Mean & 3.85 & 7.88 & 0.27 & 36.53 & 110.91 \\
\hline SEM & 0.04 & 0.32 & 0.01 & 5.66 & 7.30 \\
\hline SD & 0.37 & 2.75 & 0.08 & 48.34 & 62.34 \\
\hline Minimum & 3.17 & 1.45 & 0.08 & 0.95 & 39.79 \\
\hline Maximum & 4.92 & 13.45 & 0.43 & 321.91 & 374.53 \\
\hline $\mathrm{CV} \%$ & 9.64 & 34.88 & 29.79 & 132.32 & 56.21 \\
\hline
\end{tabular}

$S E M=$ Standard error of the mean; $S D=$ Standard deviation

Soil pH

The $\mathrm{pH}$ is an important parameter which helps to identify chemical nature of the soil (Shalini et al., 2003).

High acidity is a major constraint in the different research domains of Nepal Agricultural Research Council (Khadka et al., 2016a; Khadka et al., 2016c). The pH of soil varied from 3.17 to 4.92 with a mean of 3.85 (Table 4). This indicates very acidic $\mathrm{pH}$ (Figure 4). The $\mathrm{pH}$ showed low variability $(9.64 \%)$ among the soil samples. The different acidic soil parent materials like quartz, granite, rhyolite etc. might be the cause of high acidity (Brady and Weil, 2004). Similarly, being eastern high hills where precipitation is high and runoff is more due to sloppy land, might causes loss of basic cations also 
increases acidity. High acidity causes loss of basic cations, increases phototoxic elements such as $\mathrm{Al}$ and Mn; reduces beneficial microbial population, deteriorates soil structure (Nduwumuremyi, 2013), hence causes problem for growth and development of plants. The use of agriculture lime is important for soil acidity amelioration. Moreover, this research farm can be used for studying acidic soil environment like identification of acidic tolerant genotypes, disease, insect and pest interaction etc.

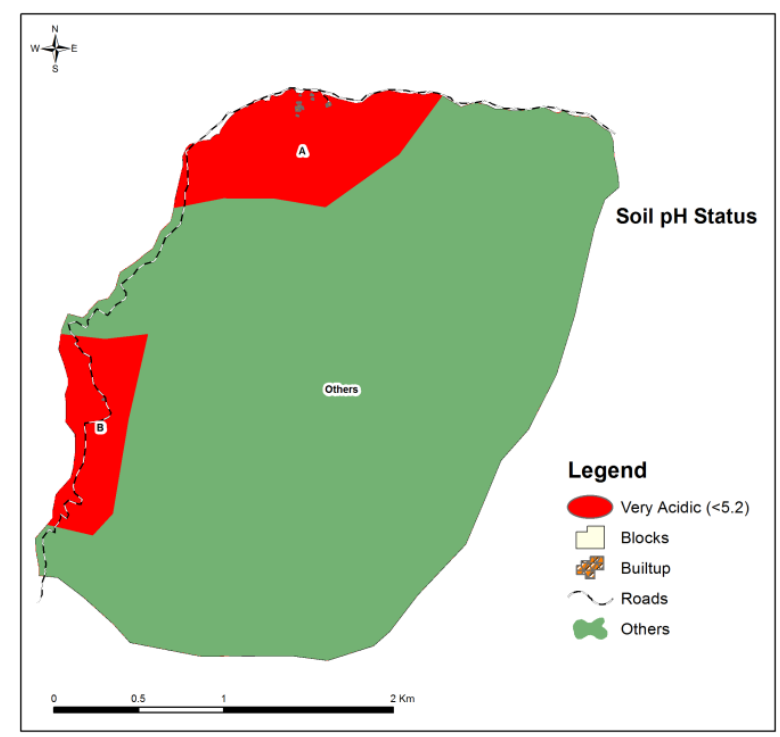

Figure 4. Soil pH Status of Agricultural Research Station, Jaubari, Illam, Nepal

\section{Organic Matter}

Organic matter is key parameters for making soil alive, because it strengthens different physical, biological and chemical properties (Hoyle et al., 2011). The organic matter varied from 1.45 to $13.45 \%$ with a mean of $7.88 \%$ (Table 4).This shows high organic matter status (Figure 5; Table 7). Organic matter showed moderate variability $(34.88 \%)$ among the soil samples. This farm was not used for cultivation, fallow from longer period of time, seen as a grazing land. The temperature is low in all around the year because of high altitude. Low human influence as well as cool temperature in all around the year reduces mineralization activity in the soil might be the cause of high organic matter status. 


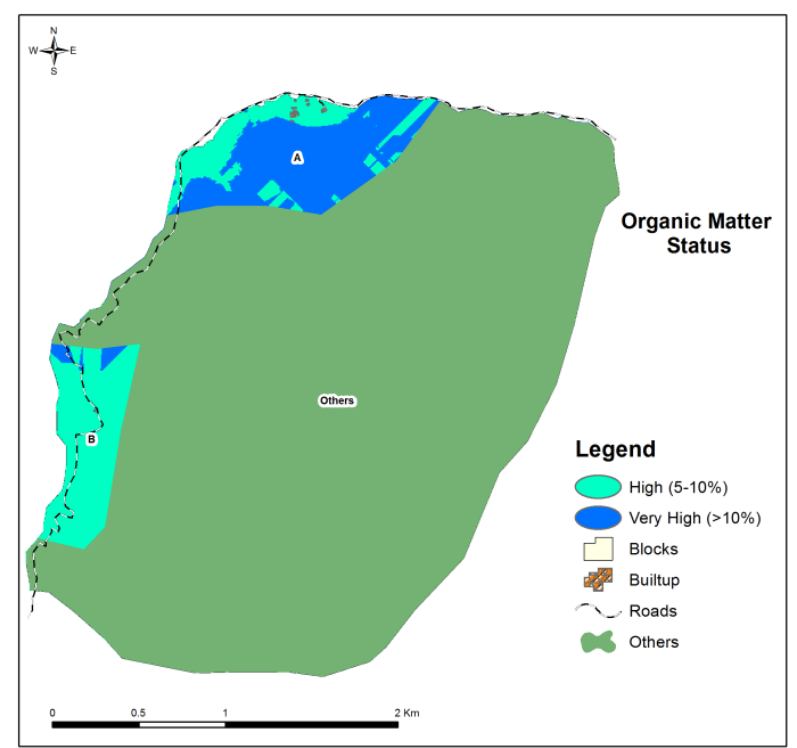

Figure 5. Organic Matter Status of Agricultural Research Station, Jaubari, Illam, Nepal

\section{Total Nitrogen}

Nitrogen is most important element required for plants in the greatest amount, which comprises about 1.5-2.0\% of plant dry matter, besides approximately $16 \%$ of total plant protein (Lima et al., 2007; Alvarez et al., 2012). The total nitrogen ranged from 0.08 to $0.43 \%$ with a mean of $0.27 \%$ (Table 4 ). This indicates high content of total nitrogen (Figure 6; Table 7). Moderate variability (29.79\%) in total nitrogen was observed among the studied samples. Nitrogen is a major component of organic matter (Brady and Weil, 2004). The adequate content of organic matter might be the cause of high total nitrogen status. Being high content of total nitrogen, $40 \%$ of the recommended nitrogen dose is required for adequate supply of nitrogen for crops in the farm (Joshi and Deo, 1975). 


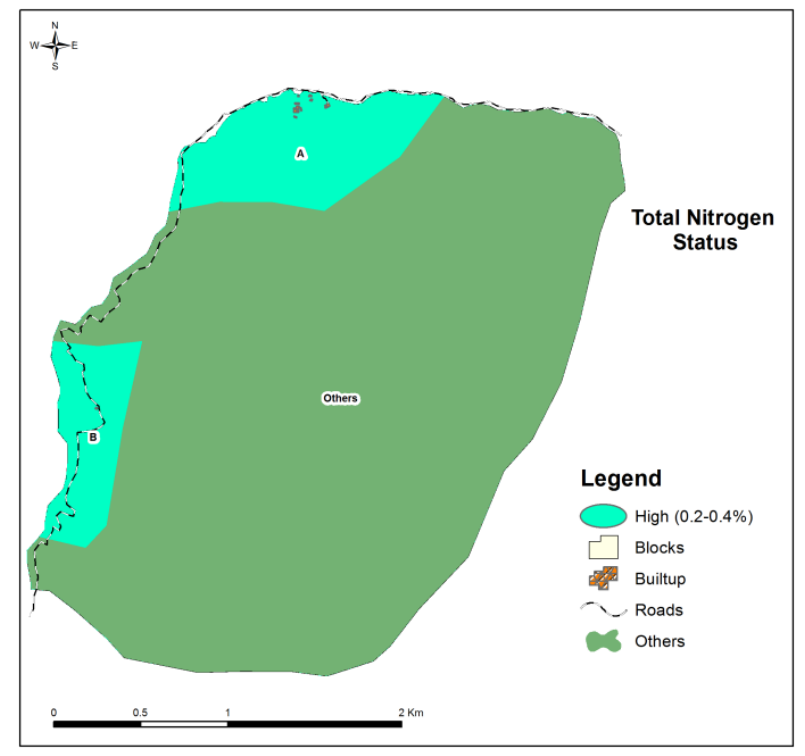

Figure 6. Total Nitrogen Status of Agricultural Research Station, Jaubari, Illam, Nepal Available Phosphorus

Phosphorus is known as the master key to agriculture because lack of available $\mathrm{P}$ in the soils reduces the growth of both cultivated and uncultivated plants (Foth and Ellis, 1997).The available phosphorus $\left(\mathrm{P}_{2} \mathrm{O}_{5}\right)$ ranged from 0.95 to $321.91 \mathrm{mg} / \mathrm{kg}$ with a mean of $36.53 \mathrm{mg} / \mathrm{kg}$ (Table 4). This show high status of available phosphorus (Figure 7; Table 7).Available phosphorus showed high variability (132.32\%) among the soil samples. The area having low, medium and high status, 100\%, 60\% and 40\%, respectively of recommended phosphorus dose should be sufficient for the crops in the farm (Joshi and Deo, 1975). 


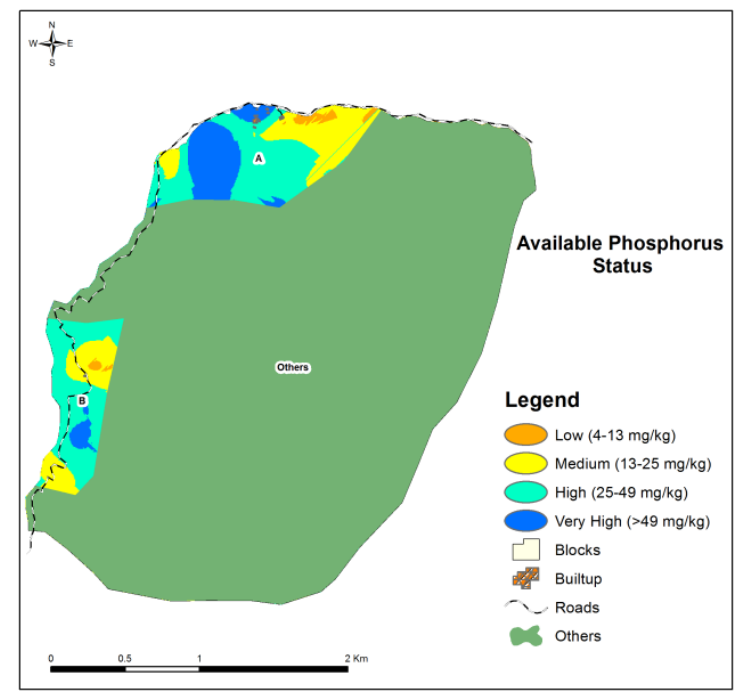

Figure 7. Available Phosphorus Status of Agricultural Research Station, Jaubari, Illam, Nepal

\section{Available Potassium}

Potassium is an essential macronutrient for plants involved in many physiological processes (Amtmann and Francisco, 2012).The available potassium $\left(\mathrm{K}_{2} \mathrm{O}\right)$ ranged from 39.79 to $374.53 \mathrm{mg} / \mathrm{kg}$ with a mean of $110.91 \mathrm{mg} / \mathrm{kg}$. This suggests medium status of available potassium (Figure 8; Table 7).High variability $(56.21 \%)$ in available potassium was determined among the soil samples. The area having medium and high status, $60 \%$ and $40 \%$, respectively of recommended potassium dose should be sufficient for the crops in the farm (Joshi and Deo, 1975).

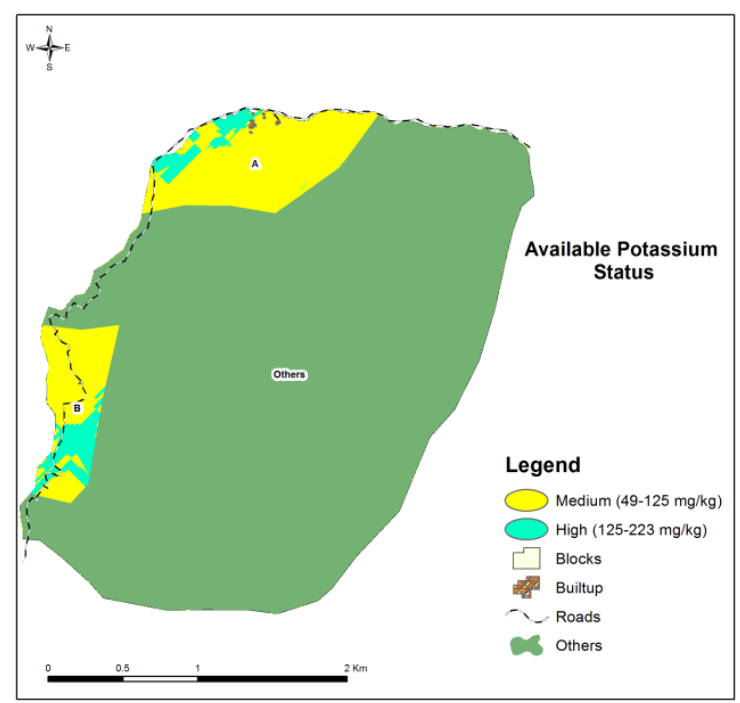

Figure 8. Available Potassium Status of Agricultural Research Station, Jaubari, Illam, Nepal 


\section{Available Calcium}

Calcium is important secondary nutrients required for cell growth, division, elongation, and various essential biological functions (Hirschi, 2004). The available calcium ranged from 20 to $1610 \mathrm{mg} / \mathrm{kg}$ with a mean of $188.70 \mathrm{mg} / \mathrm{kg}$ (Table 5).This indicates low status of available calcium (Figure 9; Table 7).High variability $(140.64 \%)$ in available calcium was observed among the soil samples. At low $\mathrm{pH}$ the availability of calcium is low (Havlin et al., 2010). The occurrence of high acidity (Figure 4) might be the cause of low amounts of available calcium. Therefore, amelioration of soil acidity is prerequisite for increasing calcium availability.

Table 5. Soil Fertility Status of Agricultural Research Station, Jaubari, Illam, Nepal

\begin{tabular}{lllll}
\hline \multirow{2}{*}{ Descriptive Statistics } & \multicolumn{4}{c}{ Soil Fertility Parameters } \\
\cline { 2 - 5 } & $\mathrm{Ca}$ & $\mathrm{Mg}$ & $\mathrm{S}$ & $\mathrm{B}$ \\
\cline { 2 - 5 } & & 50.98 & $\mathrm{mg} / \mathrm{kg}$ & 0.59 \\
Mean & 188.70 & 5.00 & 0.15 & 0.26 \\
SEM & 31.30 & 42.40 & 1.23 & 0.52 \\
MD & 265.40 & 1.20 & 0.03 & 0.01 \\
Maximum & 20.00 & 229.20 & 7.01 & 4.39 \\
CV\% & 1610.00 & 83.16 & 209.01 & 201.77 \\
\hline
\end{tabular}

$S E M=$ Standard error of the mean; $S D=$ Standard deviation

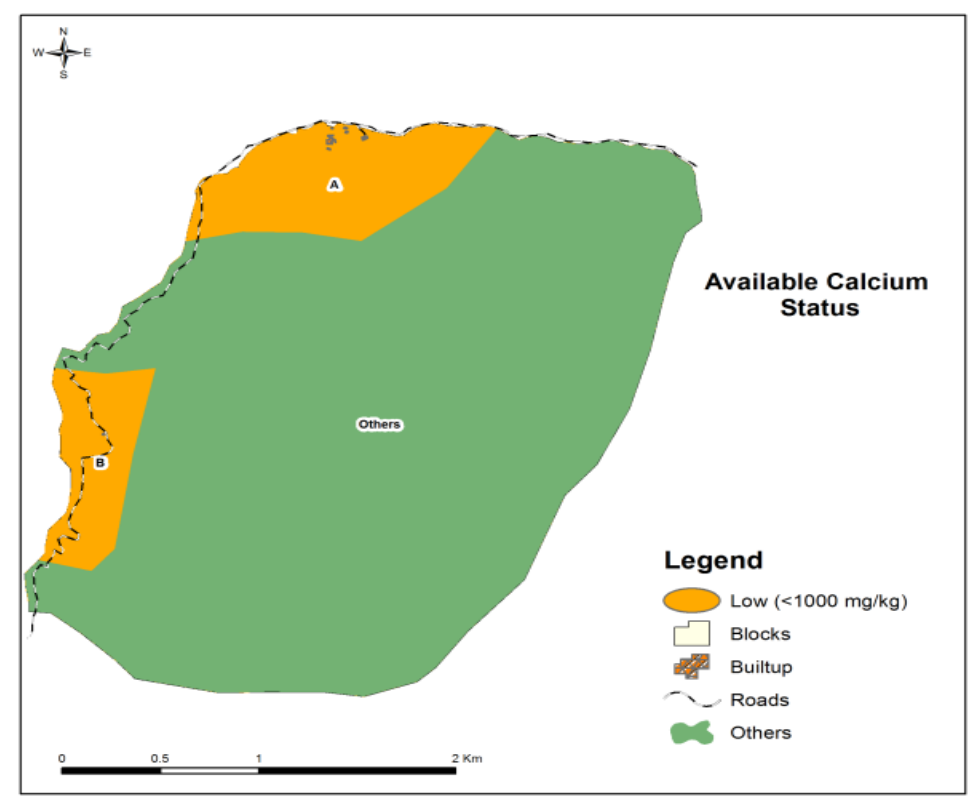

Figure 9. Available Calcium Status of Agricultural Research Station, Jaubari, Illam, Nepal 


\section{Available Magnesium}

Magnesium is a central atom of chlorophyll, and its amount has been found to be $0.2-0.4 \%$ of the dry matter in the plants (Marschner, 2012; Chen and Ma, 2013).The available magnesium ranged from 1.20 to $229.20 \mathrm{mg} / \mathrm{kg}$ with a mean of $50.98 \mathrm{mg} / \mathrm{kg}$ (Table 5). This reveals low content of available magnesium (Figure 10; Table 7). The variation (83.16\%) in the available magnesium of the observed samples was high. Like $\mathrm{Ca}$, at low pH the availability of magnesium is also low (Havlin et al., 2010). The occurrence of high acidity (Figure 4) might be the cause of low amounts of available magnesium. Therefore, amelioration of soil acidity is prerequisite for increasing magnesium availability.

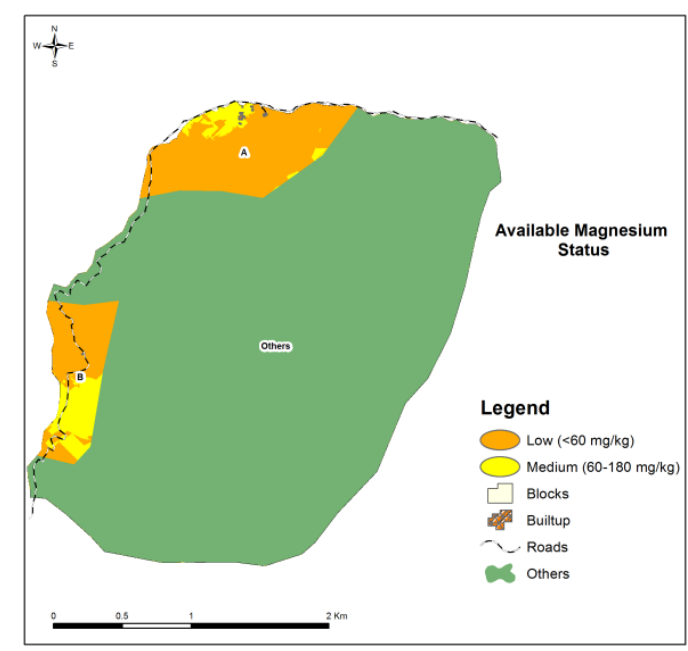

Figure 10. Available Magnesium Status of Agricultural Research Station, Jaubari, Illam, Nepal

\section{Available Sulphur}

Sulfur is the ninth richest element on the earth's crust, plays a crucial role in the synthesis of chlorophyll, proteins, seeds oil content, as well as amino acids methionine and cysteine (Jamal et al., 2010). Sulphur is also a major limiting elements in the different research domains of Nepal Agricultural Research Council (Khadka et al., 2016a; Khadka et al., 2016b; Khadka et al., 2016d; Khadka et al., 2017).The available sulphur varied from 0.03 to $7.01 \mathrm{mg} / \mathrm{kg}$ with a mean of $0.59 \mathrm{mg} / \mathrm{kg}$ (Table 5). This indicates very low available sulphur status (Figure 11; Table 7). Available sulphur showed high variability (209.01\%) in the soil samples. The sulphate ion $\left(\mathrm{SO}_{4}^{-2}\right)$ being anion, possess high potentiality to loss due to various factors (Havlin et al., 2010). The studied site being eastern sites of Nepal, possess high yearly rainfall. High leaching loss of sulphate ion due to high rainfall and sloppy land might be the cause of low sulphur. The 
management of sulphur is critical in the farm because most of the sulphur fertilizer reduces $\mathrm{pH}$ of the soil, where soil $\mathrm{pH}$ is already very acidic in the farm (Figure 4).

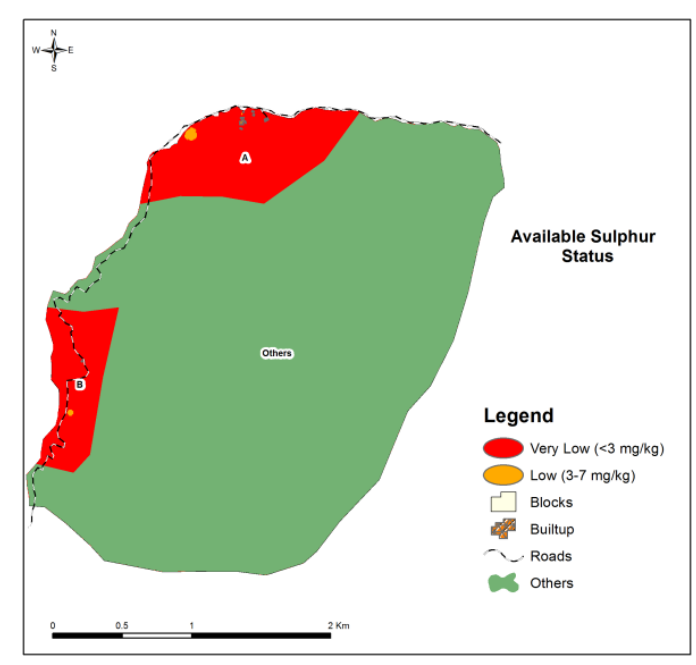

Figure 11. Available Sulphur Status of Agricultural Research Station, Jaubari, Illam, Nepal

\section{Available Boron}

Boron plays important roles in plants for sugar transport, cell wall synthesis, lignification, cell wall structure integrity, carbohydrate metabolism, ribose nucleic acid (RNA) metabolism, respiration, indoleaceticacid (IAA) metabolism, phenol metabolism, and acts as part of the cell membranes (Gupta et al., 2011).Boron deficiency has been identified as a serious agricultural issue in more than 100 crops in 80 countries (Shorrocks, 1997).Moreover, boron is a major limiting elements in the different research domains of Nepal Agricultural Research Council (Khadka et al., 2016a; Khadka et al., 2016b; Khadka et al., 2016d; Khadka et al., 2017).The available boron ranged from 0.01 to $4.39 \mathrm{mg} / \mathrm{kg}$ with a mean of $0.26 \mathrm{mg} / \mathrm{kg}$ (Table 5). This indicates very low content of available boron (Figure 12; Table 7). High variability (201.77\%) in available boron was observed among the soil samples. Being inadequate boron, application of 2-3 kg B/ha/year is advisable for reducing boron deficiency stress for plants (Khatri-Chettri, 1991). 


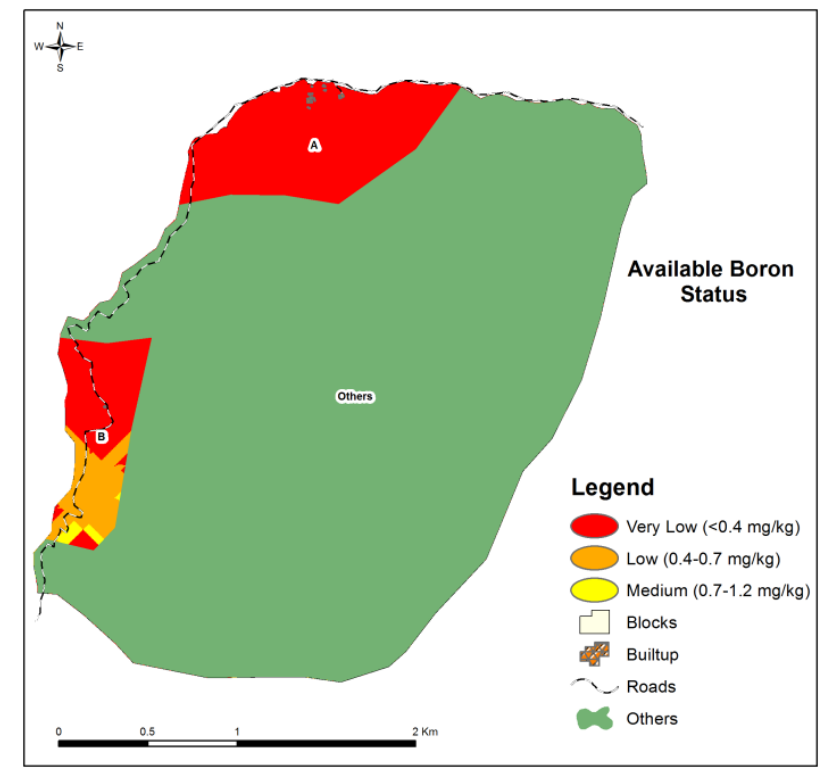

Figure 12. Available Boron Status of Agricultural Research Station, Jaubari, Illam, Nepal

\section{Available Iron}

Iron is an essential micronutrient for completion of plants lifecycle because of it plays critical role in various metabolic processes such as DNA synthesis, respiration, and photosynthesis (Rout and Sahoo, 2015).Very high content of available iron is also another major limiting factor in the different research domains of Nepal Agricultural Research Council ((Khadka et al., 2015; Khadka et al., 2016a; Khadka et al., 2016b; Khadka et al., 2016c; Khadka et al., 2016d; Khadka et al., 2017).The available iron varied from 18.26 to $412.58 \mathrm{mg} / \mathrm{kg}$ with a mean of $116.06 \mathrm{mg} / \mathrm{kg}$ (Table 6).This shows very high status of available iron (Figure 13; Table 7). Available iron showed high variability (53.98\%) among the soil samples. The very acidic $\mathrm{pH}$ as well as possibility of primary and secondary iron minerals such as hematite, olivine, siderite, goethite, magnetite etc. might be the cause of high content of available iron. Similarly, high iron availability reduces the uptake of different plant essential nutrients such as P, K, $\mathrm{Mn}$ and $\mathrm{Zn}$; thus shows deficiency stress of these elements in the plants (Fagaria et al., 2008). Therefore, proper care should be taken for reducing deficiency stress of these antagonistic elements. The amelioration of soil acidity is prerequisite for reducing iron availability, hence reduces toxicity stress for plants. 
Table 6. Soil Fertility Status of Agricultural Research Station, Jaubari, Illam, Nepal

\begin{tabular}{lllcl}
\hline \multirow{2}{*}{ Descriptive Statistics } & \multicolumn{4}{c}{ Soil Fertility Parameters } \\
\cline { 2 - 5 } & Fe & Zn & $\mathrm{Cu}$ & $\mathrm{Mn}$ \\
\cline { 2 - 5 } & \multicolumn{4}{c}{$\mathrm{mg} / \mathrm{kg}$} \\
Mean & 116.06 & 1.19 & 0.95 & 5.16 \\
SD & 7.28 & 0.31 & 0.05 & 0.90 \\
Minimum & 62.64 & 2.70 & 0.47 & 7.71 \\
Maximum & 18.26 & 0.10 & 0.34 & 0.34 \\
CV\% & 412.58 & 20.32 & 2.28 & 41.76 \\
\hline
\end{tabular}

SEM=Standard error of the mean $S D=$ Standard deviation

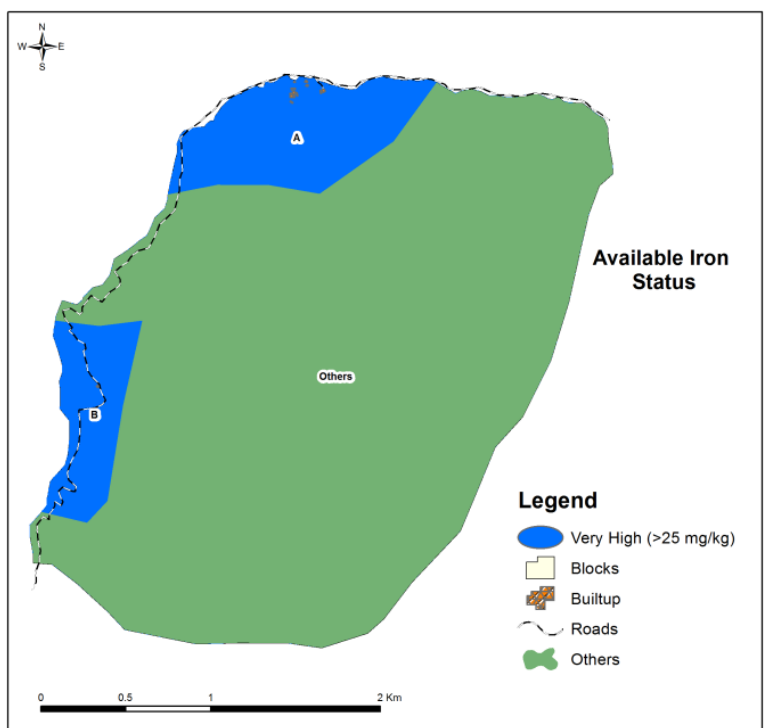

Figure 13. Available Iron Status of Agricultural Research Station, Jaubari, Illam, Nepal

\section{Available Zinc}

Zinc is requires in plants for various biochemical processes such as cytochrome and nucleotide synthesis, auxin metabolism, chlorophyll production, enzyme activation, as well maintenance of membrane integrity (Havlin et al., 2010).The available zinc ranged from 0.10 to $20.32 \mathrm{mg} / \mathrm{kg}$ with a mean of $1.19 \mathrm{mg} / \mathrm{kg}$ (Table 6).This indicates medium status of available zinc (Figure 14; Table 7). The available zinc showed high variability (226.64\%) among the soil samples. Being inadequate zinc, application of 4-8 $\mathrm{kg} \mathrm{Zn/ha} \mathrm{is} \mathrm{advisable} \mathrm{for} \mathrm{reducing} \mathrm{zinc} \mathrm{deficiency} \mathrm{stress} \mathrm{for} \mathrm{plants} \mathrm{(Khatri-Chettri,} \mathrm{1991).}$ 


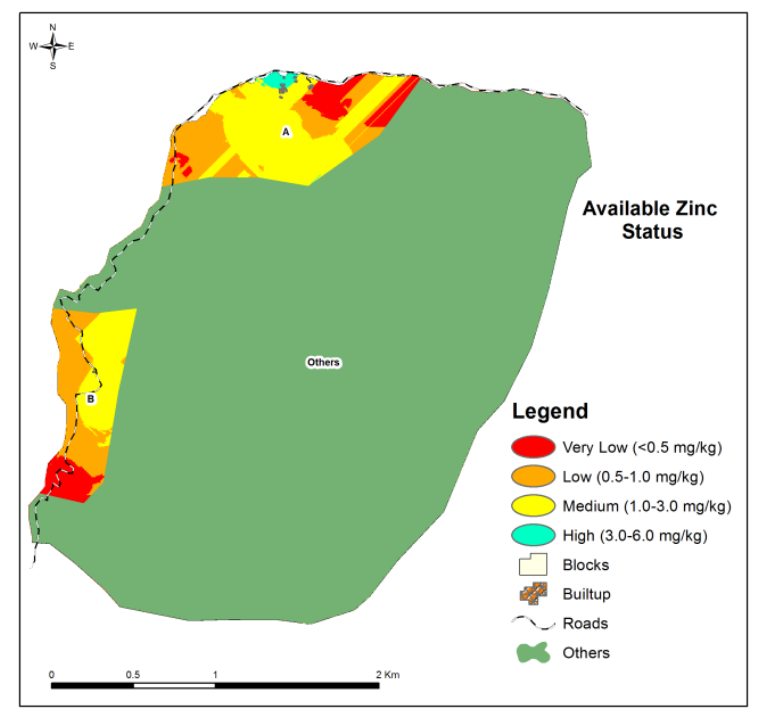

Figure 14. Available Zinc Status of Agricultural Research Station, Jaubari, Illam, Nepal

\section{Available Copper}

Copper is also an important micronutrient, required for lignin synthesis and acts as a constituent of ascorbic acid, oxidase, phenolase and plastocyanin in plants (Havlin et al., 2010). The available copper varied from 0.34 to $2.28 \mathrm{mg} / \mathrm{kg}$ with a mean of $0.95 \mathrm{mg} / \mathrm{kg}$ (Table 6). This indicates medium status of available copper (Figure 15; Table 7).High variability (49.1\%) in available copper was recorded among the soil samples. Those sites copper content is inadequate; application of $2-7 \mathrm{~kg} \mathrm{Cu} / \mathrm{ha} / \mathrm{year}$ is advisable for reducing copper deficiency stress to plants (Khatri-Chettri, 1991).

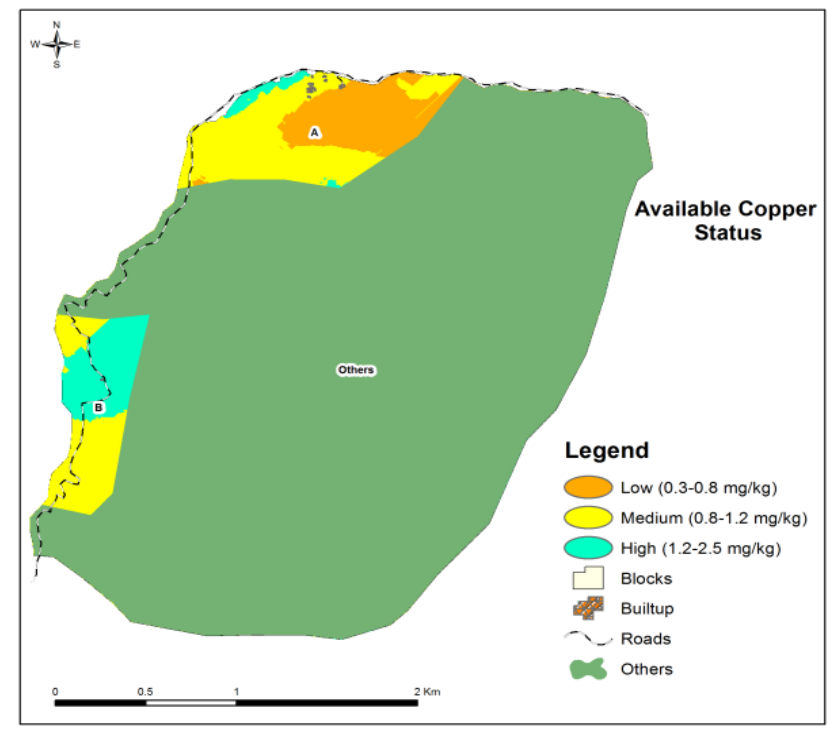

Figure 15. Available Copper Status of Agricultural Research Station, Jaubari, Illam, Nepal 


\section{Available Manganese}

Manganese is an essential micronutrient for plant, because it serves as a cofactor, activating numerous enzymes involved in the catalysis of oxidation-reduction, decarboxylation and hydrolytic reactions (Mousavi et al., 2011).The available manganese varied from 0.34 to $41.76 \mathrm{mg} / \mathrm{kg}$ with a mean of $5.16 \mathrm{mg} / \mathrm{kg}$ (Table 6). This indicates low status of available manganese (Figure 16; Table 7). The available manganese showed high variability (149.44\%) among the studied soil samples. Being inadequate manganese, application of $8-16 \mathrm{~kg} \mathrm{Mn} / \mathrm{ha} /$ year is advisable for reducing manganese deficiency stress for plants (Khatri-Chettri, 1991).

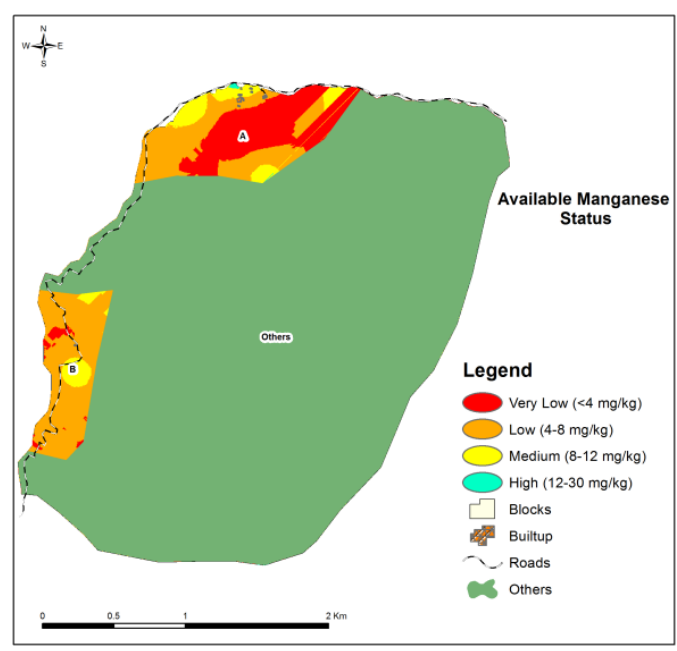

Figure 16. Available Manganese Status of Agricultural Research Station, Jaubari, Illam, Nepal 
Table 7. Nutrient indices of studied parameters of Agricultural Research Station, Jaubari, Illam, Nepal

\begin{tabular}{|c|c|c|c|c|c|c|c|c|}
\hline \multirow[b]{2}{*}{ S.N. } & \multirow[b]{2}{*}{ Parameters } & \multicolumn{5}{|c|}{$\%$ distribution of samples } & \multirow{2}{*}{$\begin{array}{l}\text { Nutrient } \\
\text { index }\end{array}$} & \multirow[b]{2}{*}{ Remarks } \\
\hline & & Very Low & Low & Medium & High & Very High & & \\
\hline 1. & $\mathrm{OM}$ & 0 & 4 & 10 & 60 & 26 & 2.82 & High \\
\hline 2. & $\mathrm{~N}$ & 0 & 1 & 14 & 82 & 3 & 2.79 & High \\
\hline 3. & $\mathrm{P}_{2} \mathrm{O}_{5}$ & 5 & 18 & 27 & 33 & 16 & 2.23 & Medium \\
\hline 4. & $\mathrm{~K}_{2} \mathrm{O}$ & 0 & 5 & 70 & 18 & 7 & 2.16 & Medium \\
\hline 5. & $\mathrm{Ca}$ & 0 & 8 & 96 & 0 & 0 & 1.03 & Low \\
\hline 6. & $\mathrm{Mg}$ & 0 & 10 & 131 & 0 & 0 & 1.34 & Low \\
\hline 7. & $\mathrm{~S}$ & 94 & 4 & 1 & 0 & 0 & 1.01 & Low \\
\hline 8. & $\mathrm{~B}$ & 90 & 7 & 1 & 0 & 1 & 1.04 & Low \\
\hline 9. & $\mathrm{Fe}$ & 0 & 0 & 0 & 3 & 97 & 3.00 & High \\
\hline 10. & $\mathrm{Zn}$ & 47 & 32 & 15 & 1 & 4 & 1.26 & Low \\
\hline 11. & $\mathrm{Cu}$ & 0 & 46 & 24 & 30 & 0 & 1.81 & Medium \\
\hline 12. & $\mathrm{Mn}$ & 62 & 24 & 5 & 5 & 3 & 1.22 & Low \\
\hline
\end{tabular}

\section{Conclusion}

The determined soil test data can be used in two aspects. First one is for sustainable soil management, while another is for developing research strategy based on the determined soil database. The physical properties signify that the current status is satisfactory for agriculture purpose. Low $\mathrm{pH}$ is a major limiting factor for proper growth and development of crops in the farm. Amelioration of soil acidity is important to reduce negative impacts of soil acidity for the sustainable soil fertility management. The fertilizer should be applied for each crops based on the determined nutrient status in the farm. The plants may suffer from deficiency stress of low, and toxicity stress of very high status of nutrients. The proper care should be taken for such types of nutrients. For enhancing research efficacy in the farm, the future research strategies should be developed based on the current soil fertility status. This farm can be used as a pocket research site, especially for very high soil acidity.

\section{Acknowledgement}

The authors would like to acknowledge Nepal Agricultural Research Council for funding this research. We are very much thankful to Agricultural Research Station, Jaubari, Illam for their cooperation. Similarly, support of the Soil Science Division, Khumaltar for providing laboratory facilities to analyze 
the soil samples and preparation of soil fertility maps as well as other technical support is highly acclaimed.

\section{References}

Alvarez, J.M. Vidal, E.A. and Gutiérrez, R.A., 2012. Integration of local and systemic signaling pathways for plant N responses. Current Opinion in Plant Biology, 15(2):185-191.

Amtmann, A. and Francisco, R., 2012. Potassium in Plants. In: eLS. John Wiley \& Sons Ltd, Chichester.

Aweto, A.O., 1982. Variability of upper slope soils developed under sandstones in South-western Nigeria. Georgian Journal 25:27-37.

Berger, K. C., and Truog, E., 1939. Boron determination in soils and plants. Industrial and Engineering Chemistry Analytical Edition, 11(10): 540-545.

Bouyoucos, G. J., 1962. Hydrometer method improved for making particle size analyses of soils. Agronomy Journal 54(5): 464-465.

Brady, N. C. and Weil, R.R., 2002.The nature and properties of soils.13th edition. Pearson Education, New Jersey.

Bremner, J. M. andMulvaney, C. S., 1982.Nitrogen total. In: Methods of soil analysis. Agron. No. 9, Part 2: Chemical and microbiological properties. 2nd edition. (A. L. Page, ed). American Society of Agronomy, Madison, WI, USA. pp. 595-624.

Cambardella, C. A. and Karlen D. L., 1999.Spatial analysis of soil fertility parameters. Precision Agriculture 1: 5-14.

Chen, Z.C. and Ma, J.F., 2013. Magnesium transporters and their role in Al tolerance in plants. Plant Soil $368: 51-56$

Das, D.K. 2004.Role of geoinformatics in sustainable agriculture: Research, extension and service to the farmers. Chairman's address. In: Proceedings of the symposium Geoinformatics Applications for Sustainable Development, 1-11, Indian Society of Agro-physics, IARI, New Delhi. 
Das, D.K. Bandyopadhyay, S. Chakraborty, D. and Srivastava, R., 2009. Application of Modern Techniques in Characterization and Management of Soil and Water Resources. Journal of the Indian Society of Soil Science 57(4):445-460.

El Mahi, Y. E. Ibrahim, I. S. Abdel Magid, H. M. and Eltilib, A. M. A., 1987. A simple method for the estimation of calcium and magnesium carbonates in soils. Soil Science Society of America Journal 51(5): 1152-1155.

Fageria, N. K. Santos, A. B. Filho, M.P. and Guimaries, C. M., 2008. Iron toxicity in lowland rice. Journal of Plant Nutrition, 31: 1676-1697.

Foth HD and BG Ellis. 1997. Soil fertility. 2nd ed. LLC., USA: Lewis CRC Press, 290pp.

Foth, H.D., 1990. Fundamentals of soil science. John Wiley \& Sons, New York.

Grace, P.R. and Weier, K.L., 2007. Soil health assessment users guide 2007 version 1. Queensland University of Technology: Brisbane. 47pp.

Gupta, P.K., 2004. Soil, plant, water and fertilizer analysis, Shyam Printing Press, Agrobios, India. 38pp.

Havlin, H.L. Beaton, J.D. Tisdale, S. L. and Nelson, W. L., 2010. Soil Fertility and Fertilizers- an introduction to nutrient management. $7^{\text {th }}$ edition. PHI Learning Private Limited, New Delhi. $515 \mathrm{pp}$.

Hirschi, K.D., 2004. The calcium conundrum.Both versatile nutrient and specific signal. Plant Physiology 136:2438-2442.

Hoyle, F.C. Baldock, J.A. and Murphy, D.V., 2011. Soil organic carbon - role in rainfed farming systems: with particular reference to Australian conditions. In: Tow, P., Cooper, I., Partridge I. and Birch C. (editors) Rainfed farming systems. Springer: New York, NY.pp. 339-361.

Jackson, M. L., 1973. Soil chemical analysis.Prentice Hall of India Pvt. Ltd., New Delhi.

Jamal, A. Moon, Y.S. and Abdin, .M.Z., 2010.Sulphur-a general overview and interaction with nitrogen. Australian Journal of Crop Science 4(7):523-529.

Joshy, D. and Deo, G.P., 1976. Fertilizers Recommendations for Major crops of Nepal.Division of Soil Science and Agricultural Chemistry, Department of Agriculture, HMG/Nepal. 
Khadka, D. Lamichhane, S. Khan, S. Joshi, S. and Pant, B., 2016d. Assessment of soil fertility status of Agriculture Research Station, Belachapi, Dhanusha, Nepal. Journal of Maize Research and Development 2(1): 43-57. doi: http://dx.doi.org/10.3126/jmrd.v2i1.16214

Khadka, D. Lamichhane, S. Malla, R. and Joshi, S., 2016c.Assessment of Soil Fertility Status of Oilseed Research Program, Nawalpur, Sarlahi, Nepal. International Journal of Advanced Research 4(6): $1472-1483$.

Khadka, D. Lamichhane, S. Shrestha S. and Pant, B. B., 2016b.Assessment of Soil Physico-Chemical Properties of Sugarcane Research Program, Jitpur, Bara, Nepal. International Journal of Advanced Research 4(5):56-66.

Khadka, D. Lamichhane, S. Thapa, B. Baral, B.R. and Adhikari, P., 2016a. An Assessment of Soil Fertility Status of National Maize Research Program, Rampur, Chitwan, Nepal. Imperial Journal of Interdisciplinary Research 2(5):1798-1807.

Khadka, D. Lamichhane, S. Thapa, B. Rawal, N. Chalise, D. R. Vista, S.P. and Lakhe, L., 2015. Assessment of Soil Fertility Status and Preparation of Their Maps of National Wheat Research Program, Bhairahawa, Nepal. In: Proceedings of the Second National Soil Fertility Research Workshop (K.B. Karki, B.P. Tripathi, R. Manandhar, B.H. Adhikari, S.P. Vista, eds.), March 2425, 2015. Soil Science Division, Khumaltar, Lalitpur, Nepal. pp. 330-340.

Khadka, D. Lamichhane, S. Tiwari D.N. and Mishra, K., 2017.Assessment of soil fertility status of National Rice Research Program, Hardinath, Dhanusha, Nepal. International Journal of Agricultural and Environmental Research 3(1): 86-105.

Khatri-Chhetri, T.B., 1991.Introduction to Soils and Soil fertility.Tribhuvan University Institute of Agricultural and Animal Science, Rampur, Chitwan, Nepal, 233pp.

Lima, P.S. Rodrigues, V.L.P. de Medeiros, J.F. de Aquino, B.F. and da Silva, J. 2007. Yield and quality of melon fruits as a response to the application of nitrogen and potassium doses.RevistaCaatinga 20(2):43-49. 
Lindsay, W. L. and Norvell, W. A. 1978.Development of a DTPA soil test for zinc, iron, manganese, and copper. Soil science society of America journal 42(3): 421-428.

Mandal, A.K. and Sharma, R.C., 2010.Computerized Database of Salt-affected soils in Peninsular India using Geographic Information System. Journal of Indian Society of Soil Science 58(1):105-116.

Marschner, H., 2012. Mineral nutrition of higher plants, 3rd edition.Academic, London. ISBN-13:9780123849052,Pp. 1-672.

Mishra, A. Das, D. and Saren, S., 2013. Preparation of GPS and GIS based soil fertility maps for Khurda district, Odisha. Indian Agriculture 57(1):11-20.

Mousavi, S.R. Shahsavari, M. and Rezaei, M., 2011.A general overview of manganese (Mn) importance for crops production. Australian Journal of Basic and Applied Science 5(9): 1799-1803.

Nduwumuremyi, A., 2013. Soil Acidification and Lime Quality: Sources of Soil Acidity, Effects on Plant Nutrients, Efficiency of Lime and Liming Requirements. Research and Reviews: Journal of Agriculture and Allied Science 2(4):26-34.

Olsen, S. R. Cole, C. V. Watanabe, F. S. and Dean, L. A., 1954.Estimation of available phosphorus in soils by extraction with sodium bicarbonate. U. S. Dep. Agric. Circ. 9, USA. 39 pp.

Panda, S.C., 2010.Soil Management and Organic Farming.Agrobios, Bharat Printing Press, Jodhpur, India. 462pp.

Pattison, A.B. Moody, P.W. Badcock, K.A. Smith, L.J. Armour, J.A. Rasiah, V. Cobon, J.A.Gulino, L.M. and Mayer, R., 2008. Development of key soil health indicators for the Australian banana industry.Applied Soil Ecology 40: 155-164.

Ramamurthy, B. and Bajaj, J. C., 1969.Available nitrogen, phosphorus and potassium status of Indian soils. Fertilizer News 14: 25-36.

Rao, D.P. Desai, P.S. Das, D.K. and Roy, P.S., 1997. Remote Sensing Applications: Thrust Area. Journal of the Indian Society of Remote Sensing, 25:195-224.

Rout, G.R. and Sahoo, S., 2015.Role of iron in plant growth and metabolism. Reviews in Agricultural Science 3:1-24. 
Shalini K. Devenda, H.S. and Dhindsa, S.S., 2003. Studies on causes and possible remedies of water and soil pollution in Sanganer town of Pink City. Indian International Journal of Environment Science, $7(1):$ 47-52.

Verma, B. C. Swaminathan, K. and Sud, K. C., 1977.An improved turbidimetric procedure for the determination of sulphate in plants and soils.Talanta 24(1): 49-50.

Walkley, A.J. and Black, I.A., 1934. Estimation of soil organic carbon by the chromic acid titration method. Soil Science 37(1): 29-38. 